\title{
Scalar postpolitics, inclusive growth and inclusive economies: challenging the Greater Manchester agglomeration model DOI:
}

10.1093/cjres/rsaa022

\section{Document Version}

Submitted manuscript

Link to publication record in Manchester Research Explorer

Citation for published version (APA):

Deas, I., Haughton, G., \& Ward, K. (2020). Scalar postpolitics, inclusive growth and inclusive economies: challenging the Greater Manchester agglomeration model. Cambridge Journal of Regions, Economy and Society, 14(1), 179-195. https://doi.org/10.1093/cjres/rsaa022

\section{Published in:}

Cambridge Journal of Regions, Economy and Society

\section{Citing this paper}

Please note that where the full-text provided on Manchester Research Explorer is the Author Accepted Manuscript or Proof version this may differ from the final Published version. If citing, it is advised that you check and use the publisher's definitive version.

\section{General rights}

Copyright and moral rights for the publications made accessible in the Research Explorer are retained by the authors and/or other copyright owners and it is a condition of accessing publications that users recognise and abide by the legal requirements associated with these rights.

\section{Takedown policy}

If you believe that this document breaches copyright please refer to the University of Manchester's Takedown Procedures [http://man.ac.uk/04Y6Bo] or contact uml.scholarlycommunications@manchester.ac.uk providing relevant details, so we can investigate your claim.

\section{OPEN ACCESS}


Deas, I., Haughton, G. and Ward, K. (2020) Scalar postpolitics, inclusive growth and inclusive economies: challenging the Greater Manchester agglomeration model, Cambridge Journal of Regions, Economy and Society, https://doi.org/10.1093/cjres/rsaa022.

This is an Author Original Version (pre-print) of an article accepted for publication in Cambridge Journal of Regions, Economy and Society on 3 July 2020 and published by Oxford University Press.

The final published version can be accessed at https://academic.oup.com/cjres/advance-articleabstract/doi/10.1093/cjres/rsaa022/5893819

Scalar postpolitics, inclusive growth and inclusive economies: challenging the Greater Manchester agglomeration model

lain Deas, Department of Planning and Environmental Management, Manchester Urban Institute, University of Manchester, Humanities Bridgeford Street Building, Oxford Road, Manchester M13 9PL, UK. Email: iain.deas@manchester.ac.uk

Graham Haughton, Department of Planning and Environmental Management, Manchester Urban Institute, University of Manchester, Humanities Bridgeford Street Building, Oxford Road, Manchester M13 9PL, UK. Email: graham.haughton@manchester.ac.uk

Kevin Ward, Department of Geography, Manchester Urban Institute, University of Manchester, Arthur Lewis Building, Oxford Road, Manchester M13 9PL, UK. Email: graham.haughton@manchester.ac.uk 
Abstract: This article examines the changing scalar political relations underpinning English cityregional governance. Drawing on case study research in Greater Manchester, the article demonstrates how the locally-rooted rise of discourses around inclusive growth and inclusive economies have been deployed to challenge the city-region's historically dominant agglomeration-based model. Using the analytical lens of scalar postpolitics, the article shows how the earlier technocratic approach adopted by national and city-region leaders attracted criticism in the face of continuing socio-spatial inequalities within Greater Manchester. We highlight the contrasting experiences of Oldham and Trafford, two boroughs of Greater Manchester, to reveal how local geographies were central to challenging the previously dominant model and promoting new thinking around inclusive growth and inclusive economies.

Keywords: City-regional governance and policy, agglomeration, scalar postpolitics, Greater Manchester

JEL codes: H77 (Intergovernmental Relations), P48 (Political Economy, Regional Studies), R11 (Regional Economic Activity: Growth, Development, Environmental Issues, and Changes), R50 (Regional Government Analysis). 


\section{Introduction}

Recent years have seen the emergence of an economic development orthodoxy that views metropolitan city-regional institutions and initiatives as central to the promotion of agglomerative growth (see, for example, Glaeser, 2011; Katz and Bradley, 2013). Acceptance of this orthodoxy has allowed local and national policy and political elites to cohere around the development of new cityregional institutions and policies. In contrast to earlier waves of metropolitan-scale governance reform and policy innovation, contemporary city-regional institution-building has often been characterised by two defining features: a narrow focus on the promotion of economic growth, downplaying its distributive socio-spatial consequences; and until recently a tendency to eschew direct accountability to local electors and minimise external scrutiny, relying instead on governance via looser, semiformalised alliances of civic and business leaders (see, for example, Deas, 2014).

In this article, we explore the ways in which challenges to both aspects of this dominant model of cityregional governance have begun to emerge. The now extensive literature on city-regional governance devotes considerable attention to the conflicts accompanying the creation of new governance territories, particularly in relation to the geographical delimitation and political configuration of collaborative alliances of local authorities. To a large extent, these conflicts have been about narrowly defined questions of political leadership and territory, whereas a shared commitment to both a lighttouch business-like model of decision-making and a growth-first approach to economic development have often gone unquestioned among local policy actors. In this article, we extend this literature by exploring intra-metropolitan contestation of the political and economic consensus that has previously facilitated metro institution-building. We explain how competing models of local economic development have been mobilised as part of a previously undocumented repoliticisation of cityregional governance, which adds to our understanding of the contested ways in which governance territories emerge and evolve. 
In developing this argument, we draw upon the experience of Greater Manchester, the English cityregion which most clearly exemplifies the approach to institutional and policy reform that has underpinned ongoing experiments with devolved urban governance. Greater Manchester has garnered sustained interest as an exemplar of effective growth-focused metropolitan governance (among many proponents, see City Growth Commission, 2014; Derbyshire, 2014; Heseltine, 2019). Critics, by contrast, have highlighted Manchester's strategy for promoting economic growth at a cost of heightened socio-spatial inequality and inadequate democratic accountability (see, for example, Beel et al., 2017; Folkman et al., 2016; Haughton et al., 2016; Hodson et al., 2020). For its supporters, however, Greater Manchester's successes in developing effective governance and policies geared towards economic revitalisation are rooted in cohesive local political relations in and around a growth coalition that has evolved over successive decades (see, for example, Harding et al., 2010).

This article explores the shape and form of the nascent challenge to the political-economic consensus that has helped to unite this governing coalition, considering not only the shifting fortunes of cityregional institutions and policy initiatives, but also homing-in on its constituent sub-areas in order to consider the role played by actors at different spatial scales. The research involved two phases of semistructured interviews. A first round in 2014 was conducted when Greater Manchester's initial devolution deal had recently been agreed with central government. A second set of interviews in 2017-19 addressed changes in the intervening period. Interviews were held with 41 people, comprising leading politicians (including one MP, two council leaders, three other councillors), activist and voluntary organisations, and senior officers at local authority and city-regional levels and in other public sector bodies.

The paper situates itself in the wider literature on devolution and changing geographies of the English state under conditions of austerity (Jones, 2018; Pike et al., 2018). We explore how the formalisation of Greater Manchester's institutions as part of broader devolution agreements with central government has created political space which has allowed local economic development alternatives 
to emerge, challenging metropolitan political cohesion around a singular economic model. To understand this process, we develop the idea of scalar postpolitics, noting the spatiality of dissensus and the incremental erosion of Manchester's hegemonic model of agglomeration boosterism, linked to critique emerging from some of the city-region's sub-areas in response to perceptions of the Manchester-centric nature of both political leadership and economic growth. Before discussing the principal findings emerging from semi-structured interviews, we explain the role of competing models of local economic development as part of a geographically inflected postpolitics in which consensus around the agglomeration growth approach faces growing challenge.

\section{Selectivity and competition in economic models: towards a scalar postpolitical}

\section{critique}

Economic models play an important performative role in legitimising particular policy regimes (Christophers, 2014a, 2014b). Dominant models emerge at particular moments, reflecting prevailing ideologies and intellectual framings about the role of the state, individuals, societies and markets. From this perspective, "power flows through these models (some get selected, others do not), structuring their use and allowing them to perform" (Christophers, 2014a, 81). They do not simply represent the world in neutral fashion; their deployment can actively construct and transform economies, in the process privileging certain ways of seeing the world (Callon, 1998; Mackenzie, 2006; Polanyi, 1944).

Ideas around depoliticisation and postpolitical governance help us to understand how particular models achieve primacy: how they emerge, morph and mutate. Crucially there is a set of geographies to these processes, which might be thought of in terms of the scalar postpolitics of governance. The postpolitical critique of contemporary governance arrangements argues in summary that consensus about what is acceptable for political debate is actively constructed by policy elites and supporting experts, thereby setting the parameters for discussion, stifling dissent, excluding outsider voices and 
delegitimising alternative thinking (Mouffe, 2000, 2005; Rancière, 1998, 2004; Swyngedouw, 2009, 2014). The rapid growth in arms-length multi-agency governance bodies and public-private partnerships can be explained as a way of helping to improve policy formulation and delivery by providing institutional mechanisms for policy actors to share expertise and resources (Jessop, 1998). However, these bodies also replace direct electoral sanction with a series of bureaucratic forms of accountability, in the form of contracts, performance measures and evaluations against specified targets. This allows a form of governing at a distance, relational proximity replacing physical proximity in some cases (Rose and Miller, 1992). For critics, these represent new forms of technocratic engagement that shift debate out of the political sphere, reinforcing the technical and procedural emphasis of decision-making while deterring meaningful citizen involvement (Allmendinger and Haughton, 2012; Haughton et al., 2013; Swyngedouw, 2009).

Depoliticisation processes can combine in various ways to deflect, displace or defer claims for political voice, for instance by transferring deliberation over contentious issues to expert panels or enquiries (Allmendinger and Haughton, 2015). However, processes of depoliticisation do not exist in isolation. Instead, they operate in an uneven dialectic relationship with the impulse for repoliticisation, in the form of claims for the right to be heard by those rendered unheard or insignificant (Haughton and McManus, 2019). This means that while dissent can be suppressed or deflected temporarily, it resurfaces. Or as Rancière $(2004,8)$ put it, "politics is always on the point of disappearing, and thus perhaps always on the point of reappearing." From this perspective, then, attempts to subdue or manipulate open and inclusive political debate can inadvertently precipitate wider conflict.

There is an important scalar dimension to the processes of depoliticisation and repoliticisation. Building on earlier work exploring conflict around the processes and practices associated with the construction of new scales of governance (see, for example, Brenner, 2001; Jonas, 2006; MacKinnon, 2011), the spatiality of postpolitics is evident in the interplay of depoliticisation and repoliticisation. The creation of new 'soft space' governance territories can be a useful depoliticising technique for 
moving potentially sensitive or contentious decision-making beyond the compass of elected local or regional government (Haughton et al., 2013). By contrast, repoliticisation processes can mean attempts to rekindle political debate, whether by re-engaging with formal democratic institutions or by infusing 'soft' institutions with mechanisms through which ideas and antagonisms can play out (Newman, 2014; Etherington and Jones, 2018). While hegemonic narratives can emerge to legitimise particular governance innovations or policy reforms, they can be disrupted when local democratic debates become reanimated. Just as some types of state rescaling, such as soft space forms of governance, may be associated with depoliticisation, others may be linked to repoliticisation and reenergising debate within the local state.

In the following sections, we develop the idea of scalar postpolitics by exploring how processes of depoliticisation and repoliticisation have evolved in Manchester's city-region, highlighting the ways in which competing models of local economic development have been utilised as part of a reanimation of local politics.

\section{The Manchester model and its alternatives}

The much-lauded Manchester model is a mixture of multiple, inter-woven approaches linked to devolved decision-making and local public service reform, as well as economic development. This paper focuses on the latter, but before turning to detail the evolution of the Manchester model for economic development and how the challenges to it have helped shape a new scalar postpolitics, we outline the overall approach to devolved governance that has emerged, incrementally and slowly, in Greater Manchester.

The 30-year period over which city-regional institutions and policies have been constructed in Greater Manchester has been extensively documented, and so can be summarised here (e.g. Deas, 2014; Kenealy, 2016; Hincks et al. 2017). Underpinning institutional and policy innovation over this period has been a longstanding conviction that the city-region is the appropriate scale at which to nest 
devolved powers bestowed by central government. Central to this has been an argument that cityregional actors are better placed to devise innovative, locally-tailored policies to promote economic dynamism, especially in a context of competitive localism and inter-city competition. At the same time, local actors have also contended that the centre is too remote to develop policies that adequately reflect local resources and priorities, and that strengthened city-regional institutions are needed to provide the political capacity and technical know-how to coordinate policy across multiple institutions and compete to procure resources from central government (GMCA, 2019).

These views have informed policy actor thinking in the period since 1986, when the elected Greater Manchester County Council was abolished by the then Conservative central government, transferring many of its powers to the ten constituent boroughs of the city-region. Nonetheless, these now unitary local authorities agreed to continue to cooperate on certain issues under the aegis of the Association of Greater Manchester Authorities (AGMA). Following prolonged lobbying by local leaders, in 2011 Greater Manchester was designated the first statutory city-region outside London, with the creation of the Greater Manchester Combined Authority (GMCA). For both AGMA and, initially, the GMCA, political leadership and accountability rested with the leaders of the ten unitary authorities. This was justified by those involved on the basis that the ten leaders were directly accountable to local residents as elected councillors and indirectly answerable to the wider electorate as political leaders of their respective local authorities. Though true in theory, in practice there was little engagement with the local electorate over city-region decisions. Seen from a postpolitical perspective, during this early period, dissent was contained and internal discipline maintained using a range of de-politicising techniques and technocratic practices, not least the use of independent reviews by external, and purportedly apolitical, advisors (Deas, 2014; Haughton et al., 2016).

This began to change with the 2014 Devolution Deal agreed between central government and the GMCA. The devolution of further powers and resources to the city-region was contingent upon the ten local leaders accepting central government's case that city-regional leadership needed to be 
reinvigorated by creating the post of elected mayor, bringing clearer accountability to local electors. The election in 2017 of Labour's Andy Burnham as Greater Manchester's first 'metro mayor' provided for the first time since 1986 a direct line of accountability between a city-regional institution and local electors. Previously hidden intra-metropolitan political tensions were exposed during the mayoral election campaign, notably those around the uneven nature of economic growth across the city-region. At the same time, as one senior local authority official explained when interviewed in 2018 , the arrival of Burnham was important because his appointment led others to link devolved governance to wider questions about the substance of the economic model on which the city-region's governance had been constructed:

he is spatially the mayor for all areas, and he genuinely is concerned I think about, you know, are we all thriving or is it just a partial story? Everybody votes for him, so that, you know, focuses your attention doesn't it? (Local Government-6, 2018).

The political space opened in the run-up to Burnham's election has subsequently been used to challenge the previous local consensus around the purpose and form of city-regional governance and policy. Central to this consensus has been what Waite and Morgan (2018) term 'metrophilia': the notion that building city-regional institutions and developing new policies is the most effective way of encouraging agglomerative growth and promoting economic advancement. One interviewee argued that this notion, previously unchallenged to a large extent, had begun to be questioned, reflecting the onset of wider contestation within city-regional politics:

Other city-regions have much more of a debate, contestation... and lack of harmony about the way forward. Manchester had that harmony [but]... is losing that harmony. Which is a good thing. Because we have still got the same levels of enduring poverty, the same problems with public services (independent researcher 1, 2018).

In the following sections, we explain the role of competing economic models, as part of a wider scalar postpolitics, in challenging city-regional political consensus around metrophilia. We argue that rather than a dominant single model of Manchester-centric city-regional agglomerationism shaping Greater Manchester's devolution experience, a range of competing models now co-exist. This partly reflects pragmatic acceptance of experimentation by local actors within the broad devolution agreement, but 
it also stems from a growing critique of the economic growth model and the emergence of alternatives, most notably those drawing on ideas around inclusive growth (Lupton and Hughes, 2016), as well as inclusive economies (Burch and Mclnroy, 2018), foundational economies (Engelen et al., 2017) and viable economies (Steady State Manchester, 2017).

\section{Challenging the Manchester economic model}

The broad basis of the Manchester economic model is grounded in agglomeration economics (Overman et al., 2009). It envisages city-regions as dynamic nodes in the global economy, characterised by dense networks of firms and concentrations of skilled workers, underpinned by welldeveloped infrastructure, a business-friendly fiscal and physical environment, and a host of cultural assets and residential amenities. Aligning with central government narratives about 'rebalancing' the national space-economy and narrowing the productivity gap between London and the rest of the country (HM Treasury, 2015), Manchester's leaders argue that due to its size and track-record of joint working, Greater Manchester offers unrivalled scope among English city-regions for boosting local economic output and ultimately reducing the area's dependence on central government funding (Hincks et al. 2017). Crucial to this argument is an emphasis on growth-focused policies for promoting already successful areas and new growth sectors, while avoiding 'spreading the jam' too thinly to areas deemed less likely to reduce the 'productivity gap' (Overman, 2013).

While the agglomeration model continues to loom large in the thinking of the GMCA, it has drawn increased criticism, centred in particular on the continuing intractability of the city-region's socioeconomic problems and rising levels of socio-spatial inequality (Hincks, 2017; Moss and Moss, 2019). This critique has been accompanied by the emergence of alternative models for the city-region's economic development, most notably those based on inclusive growth and inclusive economies (Table 1). Interviewees suggested the term inclusive growth had been broadly welcomed and widely adopted by leaders in the city-region. It is a term that has been circulating in national and international debates for a number of years, used to signal concern that economic growth should not come at the expense 
of socio-spatial polarisation (RSA, 2017; World Economic Forum, 2017). However, there is no single definition of inclusive growth, with many concluding that it is a useful if imprecise concept (Lupton and Hughes, 2016; Lee, 2019). From a postpolitical perspective, this imprecision means the term is easily co-opted as an appeal to common-sense that allows policy-makers to demonstrate a general commitment to progressive goals, but without fundamentally challenging the core elements of the agglomeration model for economic development. As one city-regional actor commented, the inclusive growth concept is helpfully vague, "a phrase that everybody can sign up to and nobody has responsibility for" (Official 3, 2018).

[TABLE 1 HERE]

Some interviewees found inclusive growth helpful in mobilising support to develop more radical alternatives, including a Greater Manchester Cooperative Commission in 2018 and a Good Employment Charter, announced in 2019, which aimed to drive up working conditions for local people. However, inclusive growth has not been without its critics, particularly in boroughs to the east and north of Manchester, where little growth, inclusive or otherwise, has occurred in recent years. In response, officials and politicians in these areas have sought to promote a more radical model, which they refer to as an inclusive economies approach (Table 1). For some proponents of the inclusive economies approach, the problem with the term inclusive growth is that it is:

rapidly becoming a mere smokescreen, a get out phrase for the same old market liberalism, with its inbuilt social and economic injustices. By contrast, an Inclusive Economy offers a genuine progressive conceptual frame in which greater consideration is given to social benefits that flow from, and feed into, economic activity (Burch and Mclnroy, 2018, 2).

Inclusive economies is itself a rather loose term, covering a range of approaches sometimes referred to as community wealth-building. For instance, it includes efforts to seek social value in contracts, and work with local anchor institutions to reduce leakage of spending beyond a locality. This approach came to prominence nationally in relation to the well-publicised work of Preston council, advised by 
the Manchester-based Centre for Local Economic Strategies, which also worked with other local authorities such as Oldham to develop alternatives (see Chakrabortty, 2018).

Challenges to the Manchester model also emerged in relation to the Greater Manchester Spatial Framework (GMSF) (Haughton, 2019). Protests quickly emerged after the publication of the draft GMSF in late 2016. Unrest focused in particular on proposed greenbelt incursions, with numerous protest rallies and around 28,000 comments submitted as part of a statutory consultation exercise. The authors of the first draft GMSF argued during interviews that it embodied the logic of the agglomeration model by prioritising efforts to support existing centres of growth, while also addressing the emerging inclusive growth agenda:

you'd never, I don't think, see it as, Manchester or Trafford losing some growth, to be able to spread it, because I don't think that's the prevailing view of how economics works in Greater Manchester. It's not a case of trying to spread the jam more evenly (city-region official 1, 2017) one of the big phrases we use in GMSF is inclusive growth. And, clearly, we've got a Greater Manchester economy which is not at all balanced really. There's been a big, big success story around the city centre, and the whole area around the city centre... [and] around the airport... But, if you look at the north-eastern side of Greater Manchester... we've got a massive concentration of deprived wards (city-region official 2, 2014).

In some senses, the approach in the $2016 \mathrm{draft}$ GMSF reflected the continuing view that major political decisions, in this instance about the future pattern of development across the city-region, could be determined via a postpolitical, technocratic process dominated by the city-region's key leaders, and without any deeper interrogation of the pro-growth rationality that underpinned it. However, the need to produce a spatial expression of the growth approach, allied to the statutory requirement to consult the public, meant the GMSF instead helped foment major debates around alternatives.

Table 2 summarises some of the alternative thinking that emerged in response to the GMSF during the period between 2016 and 2019. Housing the Powerhouse is a lobby group of developers which argued that the ambitious jobs growth targets adopted by the GMCA meant that proposed housing numbers in the GMSF were too low. It argued for substantially more executive house building, to bring the GMSF more in-line with the ambitious economic strategy for the city-region. In contrast to this 
'growth-plus' approach, groups such as the Campaign to Protect Rural England (CPRE) argued that the release of greenbelt land was unnecessary, with the capacity of brownfield sites and smaller towns to absorb future demand for new housing yet to be exhausted.

[TABLE 2 HERE]

Also notable, but less prominent locally, has been critique and policy prescription around a viable economy approach, rooted in thinking around de-growth and ecological economics, questioning the very goal of growth that underpins the GMSF (Steady State Manchester, 2017; see also Kerschner, 2010). Another dissonant viewpoint came from a foundational economies perspective, which questioned the logic of pursuing growth in high-value new technology sectors and instead called for greater attention to the provision of basic everyday services and products, often in low paid sectors, and also covering sharing economies and the social economy (Hodson et al., 2020).

Growing local criticism of the Manchester model was important in influencing a revised second draft GMSF, published in early 2019, which offered more explicit acknowledgment of the geography of uneven development across Greater Manchester, a clearer commitment to distribute growth more evenly, and recognition of the needs of the city-region's 'left-behind places'. Alternative economic thinking also informed the Manchester Independent Prosperity Review and the Local Industrial Strategy (GMCA, 2019; HM Government, 2019). The Prosperity Review is a follow-up to the 2009 Manchester Independent Economic Review, which had sought to provide an intellectual basis for Manchester's agglomerationist growth model (Haughton et al., 2016). The Local Industrial Strategy, published jointly with central government, attempts to translate the Prosperity Review into an implementable strategy.

Table 3 shows the findings of a search for key terms in each of these three documents. Inclusive growth is used 19 times in the 2019 GMSF and nine in the Local Industrial Strategy. Inclusive economy is used only once in any of the documents and not in a way that reflects local debate about the 
approach. Foundational economies appears 13 times in the Local Industrial Strategy, but as with the Prosperity Review, it is merely used as a loose signifier for low wage sectors such as retail and social care, rather than concerns over subsistence economies and alternative coping strategies. 'Viable economies' is not used in the three documents, unsurprisingly given its emphasis on challenging the growth-first aspirations of the city-region. While agglomeration economics is rarely mentioned explicitly, there are multiple allusions to dense and concentrated economic development. For example, the Local Industrial Strategy contends that Greater Manchester is well-placed for a 'scaling-up' of key sectors, while the GMSF emphasises the designation of Manchester-Salford city centre as a Core Growth Area.

[TABLE 3 HERE]

\section{Local alternatives to the Manchester model}

The different terminology employed in these key strategic documents provides an indication of the extent to which critical alternatives to agglomeration economics have begun to call into question the taken-for-granted status of the established Manchester model. The next sections explore this further by considering the experiences of two contrasting local authorities within the ten that comprise Greater Manchester: Oldham, a borough characterised by widespread poverty, interrupted by some more affluent neighbourhoods; and Trafford, an area of relative wealth but containing pockets of marked deprivation. Table 4 provides an overview of some of the key issues at the Greater Manchester scale and in the two boroughs.

[TABLE 4 HERE]

Oldham: the 'cooperative council' as an alternative to the Manchester model

Located to the north-east of Greater Manchester, Oldham is one of the areas in which alternatives to the Manchester-centric growth model are most in evidence. A weak skills base and poor transport 
connectivity have limited Oldham's ability to capitalise upon economic opportunities concentrated to a large extent in the core of the Greater Manchester city-region (Oldham Council, 2019a). Oldham is heavily dependent on public sector employment, which accounted for $19 \%$ of its employment in 2018 , the fourth highest proportion in Greater Manchester. The inability of new private sector employment to compensate for the austerity-driven contraction of public sector jobs meant that by $2019,4.7 \%$ of Oldham's working age residents were unemployed, compared to 3.9\% in Greater Manchester and 2.9\% nationally (Oldham Council, 2019b).

Local perceptions of the borough's 'left-behind' status contributed to $61 \%$ of Oldham's electors voting to leave the EU at the 2016 referendum. This was partly a consequence of intensifying socio-economic difficulties, especially in the urbanised core in the west of the borough, encapsulated by Oldham's status as the nineteenth most deprived local authority (of 317) in England in government's 2019 indices of deprivation. Socio-economic distress has been compounded by local government service spending cuts of over $40 \%$ in real terms between $2009 / 10$ and $2016 / 17$, the sixth largest decline among English local authorities (Gray and Barford, 2018).

In responding to these cuts, Oldham has embarked on a series of reforms to local public service delivery, opting for a distinctive approach by declaring itself a 'Cooperative Council' in 2011, then in 2013 becoming a founding member of the 24-strong Cooperative Councils Innovation Network. Critically, the Oldham model, in the words of one interviewee, is one that rejects the "small state, big society kind of narrative" (Local Government-6, 2018). Instead, it envisages the council playing a critical role as an influencer, recognising the scope to harness its assets, expenditure and statutory powers by coaxing others in the public, private and voluntary sectors to behave in complementary ways.

A range of locally distinctive approaches has emerged from this philosophy, some of which have since been applied elsewhere in the city-region. For instance, Oldham is widely credited for pioneering work on its 'social value procurement framework', developing social value criteria to help determine the 
selection of the council's external contractors. The council has also begun to in-source some of its former contracted-out work, preferring to deliver the relevant services internally or establishing bespoke companies. Oldham has also committed to paying council staff a 'living wage' exceeding the statutory minimum, predating central government's launch in 2016 of a National Living Wage.

Interviews in 2014 framed the emergence of this local approach to public service reform as distinctive, but nonetheless consistent with that being promoted at GMCA level. By 2018, however, interviewees working in Oldham's key institutions had begun to express unease with what they saw as an inequitable Manchester-centric approach to growth in the city-region. As one leading local authority figure put it:

\begin{abstract}
I have a fundamental problem with the whole of the agglomeration theory... Because actually, it didn't say don't invest in places, it said invest in high productivity places. And that's the real crucial point: ...my argument is that if you judge success on GM meeting an average outcome... what it masks is huge differentials both within boroughs... but also between boroughs... Because the danger is Oldham or Rochdale or whatever could fall off the edge of the world and Greater Manchester would still be [seen as] a success (Local Government-6, 2018).
\end{abstract}

This agglomerative growth model was said to have rendered areas like Oldham as 'peripheral', struggling to salvage whatever benefits they could from an essentially trickle-down (or trickle-out) approach, as one interviewee argued:

Well, my view is that I don't think that strategy has worked [in the past], so why do we think it's going to work now?... It doesn't actually help us in terms of inclusive economy (Community Organisation-3, 2018).

The inclusive growth concept was also seen as inappropriate in the context of Oldham, given its absence of any significant recent growth. As one public sector leader commented:

Yeah, I do really [dislike inclusive growth] because, well, it shouldn't just be inclusive if it's growing, should it? This is my basic problem with it (Local Government-6, 2018).

In this context, in 2018 several interviewees argued that harnessing the potential local impact of key anchor institutions offered a better alternative: 
So they've had some work within Oldham... around anchor institutions and the way in which you can help create a more inclusive economy through the way that you procure, the way that you look at kind of supporting your staff and where you recruit your staff, and, you know, those kind of pillars of kind of good practice around social value (Community Organisation-3, 2018).

Reflecting this commitment to anchor institutions, the emphasis on promoting local social value in procurement and recruitment has been extended across most or all of Oldham's public sector.

there is a real desire to move fast on the major institutions in Oldham to see what more they can do... So, the Oldham Royal Hospital are really up for it, Oldham College are up for it as are the College and First Choice Homes. So, they are moving into a space that says the economy, the local economy of Oldham is not great, we think a lot more deeply about who we employ... what suppliers we have, what our land and property assets are doing (independent researcher, 2018).

The cooperative council concept as it has evolved in Oldham has become interwoven with inclusive economies thinking, rooted in a longstanding local tradition of broadly conceived cooperative municipalism that exists in distinction, if not opposition, to the preferred economic model brokered between city-region leaders and HM Treasury. Over the course of the 2014-18 study period, Oldham's approach came to constitute a distinct local alternative model for local economic development. By 2018, widespread unease with Greater Manchester's agglomerative growth model, and a view among some interviewees that inclusive growth was merely a postpolitical tactical contrivance to deflect growing criticism, meant that the approach pioneered in Oldham was increasingly presented as an alternative, challenging the economic development orthodoxy that hitherto underpinned political consensus in the city-region. In that respect, Oldham's experience exemplifies the dynamics of scalar postpolitics and the interplay of contested processes of depoliticisation and repoliticisation.

\section{Trafford: libertarian pragmatism}

Trafford is a relatively prosperous local government area extending south-west from the edge of Manchester's city centre towards its affluent Cheshire suburbs. Its prosperity in aggregate terms is evident in a mean gross weekly wage for full-time employees estimated in the Annual Survey of Hours and Earnings as $107 \%$ of the corresponding Greater Manchester figure - the second highest of the city-region's ten authorities in 2019 (and contrasting with a figure of 88\% for Oldham). However, 
overall economic wellbeing conceals marked socio-spatial disparity. At 191st of 317 districts nationally in England's 2019 indices of deprivation, Trafford was ranked Greater Manchester's least deprived local authority. Nevertheless, $5 \%$ of its Lower Layer Super Output Areas fell within the most deprived decile in England, all of them located in the borough's urbanised north-west (Trafford Council, 2019).

Reflecting its aggregate prosperity and its integration with the economy of Manchester's metropolitan core, in contrast to Oldham a majority (58\%) of Trafford electors voted remain in the $2016 \mathrm{EU}$ membership referendum. Data from government's Business Register and Employment Survey show that only 7\% of employment in Trafford in 2018 was in the public sector - by far the lowest in Greater Manchester. Though less obviously 'left behind' and experiencing lower reductions in local government service spending than Oldham, Trafford nonetheless experienced cuts in real terms of just under 30\% between 2009/10 and 2016/17 (Gray and Barford, 2018).

For most of the study period (2010-2019), Trafford was under Conservative rule, but following local elections in 2018 control was ceded to a Labour-led alliance. Despite historically being the only Conservative-controlled local authority in Greater Manchester, Trafford council had been supportive of working arrangements at the city-regional scale and the emphasis on promoting agglomerative growth. In line with the broader consensus across the city-region, this included support for reframing agglomerative development as compatible with inclusive growth, reflected in the decision by Trafford Partnership (2017, 4), a council-led cross-sector initiative, to rename its Growth Board an Inclusive Growth Board.

In contrast to Oldham, inclusive growth was embraced as relatively unproblematic. As one council official commented when asked about the agglomeration and inclusive growth models, the two were complementary:

we call it inclusive growth now because it shouldn't be exclusive growth... I wouldn't necessarily say I don't think the [agglomeration] model works... we all are working to make sure that... as much as possible we see the benefits where we want to see [them] rather than ... [focusing] on the city centre or on Trafford Park ... So, yeah, I think it's a bit of both really (LG-5, 2018). 
The approach under Trafford's Conservative administration can be summarised as one of 'libertarian pragmatism'. This involved a combination of a rhetorical commitment to letting individuals and local communities decide their priorities and how best to address them, and a pragmatic approach that meant that all council services were reviewed, but without imposing a preferred delivery model:

everything that we do, what's the best model, whether it's a Trust, joint venture, in-house, community hub, volunteers, whatever. What's the best model of sustaining that service over three or four years, or the longer term? (Politician 2, 2014).

Interviewees supportive of this approach argued that it provided increased scope for experimentation in the design and delivery of services. According to a former senior local authority leader, the approach offered a unique opportunity to effect far-reaching reform of a sort that had previously been off-limits, presenting a chance:

not to do things differently, but to do different things - because that's transformation. (LG-4, 2018).

In practice, the commitment to being open to all options meant that a more hybrid approach emerged: doing things differently and doing different things. Large parts of Leisure Services were transferred to an independent trust, while some parks and libraries activities were given over to community groups which had been encouraged to come forward. Other notable innovations include joint ventures set up with other councils in Greater Manchester to gain efficiencies in procurement and traffic engineering, and offering services to others in the city-region, such as a shared HR service with Greater Manchester Police and pay-roll services for schools. More controversially, Trafford entered into a 15year agreement with private contractor Amey, entitled the One Trafford Partnership, to deliver waste collection and various other services. According to one leading Labour politician interviewed just after the local elections in 2018, problems experienced with these services alongside council service cuts helped precipitate the Conservatives' loss of control. The contrast with Oldham's decision to begin insourcing contracts is stark. 
What was distinctive about Trafford, compared to others in the city-region, was its work on asset maximisation and prudential borrowing and re-investment. According to one interviewee closely involved, asset maximisation was a reaction against selling-off council land to fill a budget black-hole. Instead, in places like Altrincham's previously struggling town centre to the south of the borough, work with local property owners was intended to increase the development potential of council land and promote wider commercial revitalisation.

Prudential investment was a process by which a council could borrow money from the Treasury at preferential rates, reinvesting it elsewhere using the 'power of general competence' granted to local authorities under the 2011 Localism Act. Trafford and other councils used this to invest in revenuegenerating assets in external areas, using any resultant profit to reinvest in council services. Revised government guidance in 2017 has since sought to limit the practice of borrowing for profit rather than local need.

The Trafford approach came under growing scrutiny in the run-up to local elections in 2018, when the Conservative administration's commitment to the 2016 draft GMSF was challenged by greenbelt protesters. Trafford faced increasing difficulty in defending its position when the leader of the council, Sean Anstee, was selected as Conservative candidate for election as Greater Manchester mayor, obliging him to support unpopular proposals for future growth locations across the whole city-region. At one level, these events could be interpreted as part of the regular to-and-fro of local politics. At another level, however, they could be viewed as controversial city-regional issues of a kind that had previously largely escaped public and media scrutiny. Taken together with the mayoral elections, this gave local protest groups the rationale and the opportunity to mobilise and claim the right to be heard. The emergence of a city-regional politics in this case also provoked a reanimation of local political debate, contributing to a major political realignment within Trafford. 


\section{Conclusion}

This paper has used the notion of the scalar postpolitics of governance to generate a deeper understanding of the role played by alternative approaches to economic development in challenging local political consensus around an agglomerative growth model (see also Etherington and Jones, 2018; Gray, 2018). The Greater Manchester case study demonstrates how depoliticisation both facilitated and reflected a carefully constructed local consensus about the form and function of local economic development policy (Hincks et al., 2017). This consensus began to unravel as city-regional democratic politics re-emerged, linked to the election of Greater Manchester's first metro mayor, and as national political concern began to focus on the 'left-behind' places seemingly most affected by austerity and least able to capitalise upon new urban economic growth (Billing et al, 2019).

The Greater Manchester experience could be seen as reflecting Rancière's (2004) argument that attempts to depoliticise debate and stifle dissent are ultimately unsustainable. We have argued in this paper that the tendency to repoliticisation is evident, firstly, at a city-region scale, in the form of protest in response to the proposed Greater Manchester Spatial Framework and linked to elections for a metro mayor, both of which have served to mobilise a range of civil society actors previously marginal to the constricted debate that characterised the postpolitical mode of decision-making previously dominant in the city-region (see also Beel et al., 2017). Challenge to the postpolitical basis of decision-making has also emerged, secondly, within the city-region, as constituent local authorities like Oldham have begun to articulate approaches questioning the agglomeration logic that has previously dominated Greater Manchester's agenda.

The paper has demonstrated that the deployment of a series of alternative economic development models, and continued reform of the dominant model of agglomerative growth, can be understood in terms of the scalar postpolitics of governance. Alternative models have played contradictory roles, both reinforcing and undermining the ascendant postpolitical agglomerationist growth approach. The term inclusive growth garnered support because it allowed city-region leaders to continue to maintain 
an agglomerationist logic while also recognising the case for greater socio-spatial equity and the needs of 'left behind' places and people. Acknowledging the inclusive growth agenda proved important in allowing actors across Greater Manchester to pursue a wider range of policy agendas, while maintaining the appearance of consensus. The diffusion of the inclusive economies agenda also had a distinctive geography to it, resonating much more strongly in struggling areas such as Oldham but gaining little purchase in the very different local political context of Trafford. When the national-cityregional agglomerationist model came under greater critical local scrutiny, however, Oldham leaders were able to demonstrate their relative independence of it, whereas Trafford's leaders found themselves tied to it, their adoption of inclusive growth ideas failing to insulate them from critique.

The upshot of this is that there is no longer such a thing as a singular uncontested Manchester model. A consequence is that there are substantial risks for wider attempts to develop cohesive city-regional governance and policy. The reanimation of local contestation around competing approaches to economic development risks undermining metropolitan political cohesion and clarity of message. It also risks impairing city-region-national relations, potentially affecting resource procurement. This was evident when central government withdrew its proposed f68m Housing Deal for the city-region following publication in 2019 of the redrafted GMSF, revised in light of local concerns about housing affordability and green belt encroachment (Barratt, 2019). Offset against this, however, must be the wider range of approaches now emerging, potentially better tailored to the needs of individual boroughs, especially those to the north and east of the city-region, and creating a system-level resilience by removing reliance on just one way of thinking.

It is also possible to draw some wider conclusions about changes in the constitution of the local state and the changing nature of city-regional politics (Salet and Savini, 2015; Pike et al., 2018). The findings here suggest the direction of city-regional policy is determined via a complex multi-layered system of governance that stands in marked contrast to the Manchester-centric model that existed previously. The involvement of multiple actors and voices, and the challenges for a now statutory city-region and 
elected mayor of delivering multi-functional responsibilities while maintaining formal accountability, mean that it is more difficult to sustain a singular, coherent model for economic development. In this sense, the Greater Manchester story illustrates what happens when growth coalitions evolve, extend and formalise, with the effect that a particular model of growth becomes more difficult to pursue and support for alternatives becomes easier to mobilise.

\section{Acknowledgement}

Part of the research for this article was funded as part of a University of Manchester Humanities Strategic Investment Reserve Fund project, 'Austerity urbanism and local governance restructuring', 2013-15).

\section{References}

Allmendinger, P. and Haughton, G. (2012) Post-political spatial planning in England: a crisis of consensus? Transactions of the Institute of British Geographers, 37: 89-103.

Allmendinger P. and Haughton G. (2015) Post-political regimes in English Planning: from Third Way to Big Society. In J. Metzger, P. Allmendinger and S. Oosterlynck (eds.) Planning Against the Political: Democratic Deficits in European Territorial Governance, pp.29-53. London: Routledge.

Barratt, L. (2019) Cancelled f68m Manchester housing deal will mean 'more unaffordable housing'. Inside Housing. Available online at: https://www.insidehousing.co.uk/news/news/cancelled68m-manchester-housing-deal-will-mean-more-unaffordable-housing-61069 [Accessed 5 July 2020].

Beel, D., Jones, M., Rees Jones, I. and Escadale, W. (2017) Connected growth: developing a framework to drive inclusive growth across a city-region, Local Economy, 32: 565-575. 
Billing, C., McCann, P. and Ortega-Argiles, R. (2019) Interregional inequalities and UK sub-national governance responses to Brexit, Regional Studies, 53: 741-760.

Brenner, N. (2001) The limits to scale? Methodological reflections on scalar structuration, Progress in Human Geography, 25: 591-614.

Burch, D. and McInroy, N. (2018) We need inclusive economies not inclusive growth. Centre for Local Economic Strategies, Manchester. Available online at: https://cles.org.uk/wpcontent/uploads/2018/12/Policy-Provocation We-need-an-inclusive-economy-not-inclusivegrowth 191218.pdf [Accessed 5 July 2020].

Callon, M. (1998) The Laws of the Markets. Oxford: Wiley Blackwell.

Chakrabortty, A. (2018) In 2011 Preston hit rock bottom, then it took back control, The Guardian, 31 January. Available online at:

https://www.theguardian.com/commentisfree/2018/jan/31/preston-hit-rock-bottom-tookback-control [Accessed 5 July 2020].

Christophers, B. (2014a) Wild dragons in the city: urban political economy, affordable housing development and the performative world-making of economic models, International Journal of Urban and Regional Research, 38: 79-97.

Christophers, B. (2014b) From Marx to market and back again: performing the economy, Geoforum, 57: 12-20.

City Growth Commission (2014) Unleashing Metro Growth: Final Recommendations of the City Growth Commission, Royal Society for the Encouragement of Arts, Manufactures and Commerce, London. Available online at: https://www.thersa.org/globalassets/pdfs/reports/final-city-growth-commission-reportunleashing-growth.pdf [Accessed 5 July 2020]. 
Deas, I. (2014) The search for territorial fixes in subnational governance: city-regions and the disputed emergence of post-political consensus in Manchester, England, Urban Studies, 51: 2285-2314.

Derbyshire, J. (2014) Why Manchester works, Prospect, 19 June. Available online at: https://www.prospectmagazine.co.uk/magazine/why-manchester-works [Accessed 5 July 2020].

Engelen, E., Froud, J. Johal, S., Salento, A. and Williams, K. (2017) The grounded city: from competitivity to the foundational economy, Cambridge Journal of Regions, Economy and Society, 10: 407-423.

Etherington, D. and Jones, M. (2018) Re-stating the post-political: depoliticisation, social inequalities, and city-region growth, Environment and Planning A: Economy and Space, 50: 51-72.

Folkman, P., Froud J., Johal, S., Tomaney, J. and Williams, K. (2016) Manchester Transformed: Why we Need a Reset of City Region Policy, Centre for Research on Socio-Cultural Change. Available online at:

https://hummedia.manchester.ac.uk/institutes/cresc/research/ManchesterTransformed.pdf [Accessed 5 July 2020].

Glaeser, E. (2011) Triumph of the City: How Urban Spaces Make Us Human. London: MacMillan.

GMCA (2019) Greater Manchester Independent Prosperity Review. Available online at: https://www.greatermanchesterca.gov.uk/media/1826/gmis reviewersreport final digital.pdf [Accessed 5 July 2020].

Gray, M. and Barford, A. (2018) The depths of the cuts: the uneven geography of local government austerity, Cambridge Journal of Regions, Economy and Society, 11: 541-564.

Gray, N. (2018) Neither Shoreditch nor Manhattan: post-politics, "soft austerity urbanism" and real abstraction in Glasgow North, Area, 50: 15-23. 
Harding, A., Harloe, M. and Rees, J. (2010) Manchester's bust regime?, International Journal of Urban and Regional Research, 34: 981-991.

Haughton, G. (2019) Constrained governance rescaling and the development of a new spatial framework for Greater Manchester. In V. Lingua and V. Balz (eds.) Shaping Regional Futures: Designing and Visioning in Governance Rescaling, pp. 73-85. Berlin: Springer Nature.

Haughton, G., Allmendinger, P. and Oosterlynck, S. (2013) Spaces of neoliberal experimentation: soft spaces, post-politics and neoliberal governmentality, Environment and Planning A, 45: 217234.

Haughton, G., Deas, I., Hincks, S. and Ward, K. (2016) Mythic Manchester: Devo Manc, the Northern Powerhouse and rebalancing the English economy, Cambridge Journal of Regions, Economy and Society, 9: 355-370.

Haughton G. and McManus P. (2019) Participation in Postpolitical Times: protesting WestConnex in Sydney, Australia, Journal of the American Planning Association, 85: 321-334

Heseltine, M. (2019) Empowering English Cities, Haymarket Publishing. Available online at: https://englishcitiesmichaelheseltine.premediastudio.com/MichaelHeseltine/ [Accessed 5 July 2020].

Hincks, S. (2017) Deprived neighbourhoods in transition: divergent pathways of change in the Greater Manchester city-region, Urban Studies, 54: 1038-1061.

Hincks, S., Deas, I. and Haughton, G. (2017) Real geographies, real economies and soft spatial imaginaries: creating a 'more than Manchester' region, International Journal of Urban and Regional Research, 41: 642-657.

HM Government (2019) Greater Manchester Local Industrial Strategy, London: Department for Business, Energy and Industrial Strategy. Available online at: https://assets.publishing.service.gov.uk/government/uploads/system/uploads/attachment d 
ata/file/808917/greater-manchester-local-industrial-strategy-double-page-print-ready.pdf

[Accessed 5 July 2020].

HM Treasury (2015) Fixing the Foundations: Creating a More Prosperous Nation, CM9808. London: HMSO. Available online at:

$\underline{\text { https://assets.publishing.service.gov.uk/government/uploads/system/uploads/attachment d }}$ ata/file/443897/Productivity Plan print.pdf [Accessed 5 July 2020].

Hodson, M., McMeekin, A., Froud, J., and Moran, M. (2020) State-rescaling and re-designing the material city-region: tensions of disruption and continuity in articulating the future of Greater Manchester, Urban Studies, 57: 198-217.

Jessop, B. (1998) The rise of governance and the risks of failure: the case of economic development, International Social Science Journal, 50: 29-45.

Jonas, A. (2006) Pro scale: further reflections on the 'scale debate' in human geography, Transactions of the Institute of British Geographers, 31: 399-406.

Jones, M. (2018) The march of governance and the actualities of failure: the case of economic development twenty years on, International Social Science Journal, 68: 25-41.

Katz, B. and Bradley, J. (2013) The Metropolitan Revolution: How Cities and Metros are Fixing our Broken Politics and Fragile Economy. Washington DC: Brookings Institution Press.

Kerschner, C (2010) Economic de-growth vs. steady-state economy, Journal of Cleaner Production, 18: 544-551.

Kenealy, C. (2016) A tale of one city: the Devo Manc deal and its implications for English devolution, Political Quarterly, 87: 572-581.

Lee, N. (2019) Inclusive growth in cities: a sympathetic critique, Regional Studies, 53: 424-434.

Lupton, R. and Hughes, C. (2016) Achieving Inclusive Growth in Greater Manchester: What Can Be Done? Manchester: University of Manchester. Available online at: 
http://hummedia.manchester.ac.uk/institutes/mui/igau/IGAU-Consultation-Report.pdf [Accessed 5 July 2020].

MacKenzie, D. (2006) An Engine, Not a Camera: How Financial Models Shape Markets. Cambridge, MA: MIT Press.

MacKinnon, D. (2011) Reconstructing scale: towards a new scalar politics, Progress in Human Geography, 35: 21-36.

Moss, C. and Moss, K. (2019) Out of sight: social control and the regulation of public space in Manchester, Social Sciences, 8: 146-156.

Mouffe, C. (2000) The Democratic Paradox. London: Verso.

Mouffe, C. (2005) On the Political. London: Routledge.

Newman, J. (2014) Landscapes of antagonism: local governance, neoliberalism and austerity, Urban Studies, 51: 3290-3305.

Oldham Council (2019a) Quarterly Economic Bulletin: Winter 2019, Oldham Strategy and Performance Unit. Available online at:

https://www.oldham.gov.uk/download/downloads/id/4007/quarterly economic bulletin.pdf [Accessed 5 July 2020].

Oldham Council (2019b) Oldham in Profile, Oldham MBC Business Intelligence Service. Available online at: https://www.oldham.gov.uk/download/downloads/id/4740/oldham in profile pdf format.p df [Accessed 5 July 2020].

Overman, H. (2013) The economic future of cities, CentrePiece. Available online at: http://cep.Ise.ac.uk/pubs/download/cp389.pdf [Accessed 5 July 2020]. 
Overman, H., Gibbons, S. and Tucci, A. (2009) The Case for Agglomeration Economies, Manchester Independent Economic Review. Available online at: http://www.manchesterreview.org.uk/project 718.html [Accessed 5 July 2020].

Pike, A., Coombes, M., O’Brien, P. and Tomaney, J. (2018) Austerity states, institutional dismantling and the governance of sub-national economic development: the demise of the regional development agencies in England, Territory, Politics, Governance, 33: 118-144.

Polanyi, K. (1944) The Great Transformation. Boston: Beacon Press.

Rancière, J. (1998) Disagreement. Minneapolis, MN.: University of Minnesota Press.

Rancière, J. (2004) Introducing disagreement, Angelaki, 9: 3-9.

Rose, N. and Miller, P. (1992) Political power beyond the state: problematics of government, The British Journal of Sociology, 43: 173-205.

RSA [Royal Society for the encouragement of Arts, Manufactures and Commerce] (2017) Inclusive Growth Commission: Making Our Economy Work for Everyone. RSA: London. Available online at: https://www.thersa.org/discover/publications-and-articles/reports/final-report-of-theinclusive-growth-commission [Accessed 5 July 2020].

Salet, W. and Savini, F. (2015) The political governance of urban peripheries, Environment and Planning C: Society and Space, 33: 448-456.

Steady State Manchester (2017) Policies for the City Region. Manchester: Steady State Manchester. Available online at: https://steadystatemanchester.net/treading-lightly-for-shared-prosperitypolicies-for-greater-manchester/ [Accessed 5 July 2020].

Swyngedouw, E. (2009) The antinomies of the post-political city: in search of a democratic politics of environmental production, International Journal of Urban and Regional Research, 33: 601620. 
Swyngedouw, E. (2014) Where is the political? Insurgent mobilizations and the incipient 'return of the political', Space and Polity, 18: 122-136.

Trafford Council (2019) Relative deprivation in Trafford, Trafford Data Lab. Available online at: https://www.trafforddatalab.io/analysis/loD2019/report/ [Accessed 5 July 2020].

Trafford Partnership (2017) Annual Report 2016/17, Trafford Metropolitan Borough Council. Available online at: http://www.traffordpartnership.org/about/Docs/TP-Annual-Report2017web.pdf [Accessed 5 July 2020].

Waite, D. and Morgan, K. (2018) City Deals in the polycentric state: the spaces and politics of Metrophilia in the UK, European Urban and Regional Studies, 26: 382-399.

World Economic Forum (2017) The Inclusive Growth and Development Report 2017. World Economic Forum: Geneva. Available online at: http://www3.weforum.org/docs/WEF Forum IncGrwth 2017.pdf [Accessed 5 July 2020]. 
Table 1: Three economic models emerging in Manchester, 2009-2019

\begin{tabular}{|c|c|c|c|}
\hline Models & $\begin{array}{l}\text { Agglomerative } \\
\text { Growth }\end{array}$ & Inclusive growth & Inclusive economies \\
\hline Core idea & $\begin{array}{l}\text { Build on core } \\
\text { economic areas, } \\
\text { facilitating further } \\
\text { development. }\end{array}$ & $\begin{array}{l}\text { Address persistent spatial } \\
\text { and social inequalities } \\
\text { and promote spatially } \\
\text { and socially more } \\
\text { balanced development. }\end{array}$ & $\begin{array}{l}\text { Build from local strengths, } \\
\text { maximise the local impact of } \\
\text { anchor institutions to reduce } \\
\text { financial leakage. }\end{array}$ \\
\hline $\begin{array}{l}\text { Intellectual } \\
\text { basis }\end{array}$ & $\begin{array}{l}\text { Agglomeration } \\
\text { economics - } \\
\text { government should } \\
\text { invest in areas of } \\
\text { success and not } \\
\text { spread the jam too } \\
\text { thinly. }\end{array}$ & $\begin{array}{l}\text { Need to put more } \\
\text { emphasis on addressing } \\
\text { inequalities and poverty, } \\
\text { and deriving greater } \\
\text { social benefit from } \\
\text { economic growth. }\end{array}$ & $\begin{array}{l}\text { Localisation, community- } \\
\text { focused. Support those } \\
\text { already in area by increasing } \\
\text { local opportunities. }\end{array}$ \\
\hline $\begin{array}{l}\text { Intellectual } \\
\text { critique }\end{array}$ & $\begin{array}{l}\text { Neoliberal growth } \\
\text { model by another } \\
\text { name. Failed trickle- } \\
\text { down economics. }\end{array}$ & $\begin{array}{l}\text { Not clear yet what the } \\
\text { intellectual model is. }\end{array}$ & $\begin{array}{l}\text { Does not prioritise new jobs. } \\
\text { Relies on public sector } \\
\text { institutions constrained by } \\
\text { austerity. }\end{array}$ \\
\hline $\begin{array}{l}\text { Practice } \\
\text { critique }\end{array}$ & $\begin{array}{l}\text { Structural economic } \\
\text { weaknesses remain, } \\
\text { poverty endures, } \\
\text { trickle-down failed, } \\
\text { growth is socially and } \\
\text { spatially concentrated. }\end{array}$ & $\begin{array}{l}\text { Too easily co-opted and } \\
\text { allows business-as-usual. }\end{array}$ & $\begin{array}{l}\text { Difficult to scale-up or } \\
\text { evidence. } \\
\text { Lacks coherent narratives. }\end{array}$ \\
\hline $\begin{array}{l}\text { Related } \\
\text { discourses }\end{array}$ & $\begin{array}{l}\text { Focused growth plans } \\
\text { on key sectors. } \\
\text { Narrow productivity } \\
\text { gap with London. }\end{array}$ & $\begin{array}{l}\text { Don't forget 'left behind' } \\
\text { places and people. } \\
\text { Smaller town economies. }\end{array}$ & $\begin{array}{l}\text { Cooperative councils, } \\
\text { community wealth-building. }\end{array}$ \\
\hline
\end{tabular}


Table 2: GMSF and Greater Manchester Mayoral elections: alternative discourses

\begin{tabular}{|c|c|c|c|c|}
\hline $\begin{array}{l}\text { Alternative } \\
\text { discourses }\end{array}$ & Growth-plus & Contained growth & $\begin{array}{l}\text { Viable } \\
\text { economy }\end{array}$ & $\begin{array}{l}\text { Foundational } \\
\text { economy }\end{array}$ \\
\hline Actors & $\begin{array}{l}\text { HBF and Housing } \\
\text { the Powerhouse. }\end{array}$ & $\begin{array}{l}\text { CPRE, local } \\
\text { greenbelt groups. }\end{array}$ & $\begin{array}{l}\text { Steady State } \\
\text { Manchester. }\end{array}$ & $\begin{array}{l}\text { CRESC, University of } \\
\text { Manchester. }\end{array}$ \\
\hline $\begin{array}{l}\text { Basis of } \\
\text { critiques }\end{array}$ & $\begin{array}{l}\text { Need for more } \\
\text { homes. } \\
\text { Too much focus on } \\
\text { 'city centre living', } \\
\text { not enough on } \\
\text { family housing. }\end{array}$ & $\begin{array}{l}\text { Too much greenbelt } \\
\text { loss for high-end } \\
\text { housing and auto- } \\
\text { based development } \\
\text { near motorway } \\
\text { exits. }\end{array}$ & $\begin{array}{l}\text { Failed trickle- } \\
\text { down. } \\
\text { Ecological } \\
\text { economics. } \\
\text { De-growth. }\end{array}$ & $\begin{array}{l}\text { Not enough } \\
\text { attention to } \\
\text { improving } \\
\text { conditions for } \\
\text { majority of workers } \\
\text { in 'mundane' } \\
\text { sectors. }\end{array}$ \\
\hline $\begin{array}{l}\text { Narratives } \\
\text { and } \\
\text { discursive } \\
\text { lines }\end{array}$ & $\begin{array}{l}\text { Supportive of GM } \\
\text { scale plans } \\
\text { provided they are } \\
\text { ambitious in } \\
\text { housing } \\
\text { projections. }\end{array}$ & $\begin{array}{l}\text { Greenbelt loss. } \\
\text { Manchester airport } \\
\text { fuels the model and } \\
\text { remains } \\
\text { untouchable. }\end{array}$ & $\begin{array}{l}\text { Treading } \\
\text { lightly for } \\
\text { shared } \\
\text { prosperity. }\end{array}$ & $\begin{array}{l}\text { Address low pay } \\
\text { and poor working } \\
\text { conditions, social } \\
\text { economy and self- } \\
\text { provisioning. }\end{array}$ \\
\hline
\end{tabular}


Table 3: Textual analysis of key terms (or similar terms) mentioned in three GMCA documents published in 2019.

\begin{tabular}{|lcccl|}
\hline & $\begin{array}{l}\text { Inclusive } \\
\text { growth }\end{array}$ & $\begin{array}{l}\text { Inclusive } \\
\text { economies }\end{array}$ & $\begin{array}{l}\text { Foundational } \\
\text { economies }\end{array}$ & $\begin{array}{l}\text { Agglomeration } \\
\text { economies } \\
\text { (scale-up/core } \\
\text { growth) }\end{array}$ \\
\hline GMSF 2, 2019. & 19 & 0 & 0 & $\begin{array}{l}\text { 2 (27 references to } \\
\text { core growth) }\end{array}$ \\
\hline $\begin{array}{l}\text { Prosperity } \\
\text { Review, 2019 }\end{array}$ & 1 & 0 & 2 & 4 \\
\hline $\begin{array}{l}\text { Local Industrial } \\
\text { Strategy, 2019 }\end{array}$ & 9 & 1 & 13 & $\begin{array}{l}0 \text { (26 references to } \\
\text { large-scale, scaling up } \\
\text { or similar) }\end{array}$ \\
\hline
\end{tabular}


Table 4: Alternative models and their key characteristics: Greater Manchester, Oldham, Trafford

\begin{tabular}{|c|c|c|c|}
\hline & Greater Manchester & $\begin{array}{l}\text { Oldham: Cooperative } \\
\text { Council }\end{array}$ & $\begin{array}{l}\text { Trafford: Libertarian } \\
\text { pragmatism }\end{array}$ \\
\hline $\begin{array}{l}\text { Dominant } \\
\text { discourses }\end{array}$ & $\begin{array}{l}\text { Grow dynamic areas } \\
\text { and sectors. Public } \\
\text { sector reform. } \\
\text { Productivity gap. }\end{array}$ & $\begin{array}{l}\text { Inclusive economies. } \\
\text { Cooperative council. } \\
\text { Place-based solutions. } \\
\text { Anti-austerity. }\end{array}$ & $\begin{array}{l}\text { Solutions mainly exist in } \\
\text { communities, not government. } \\
\text { Mixed modes of delivery. }\end{array}$ \\
\hline $\begin{array}{l}\text { Approach } \\
\text { to growth }\end{array}$ & $\begin{array}{l}\text { Agglomeration and } \\
\text { core development. } \\
\text { Inclusive growth. }\end{array}$ & $\begin{array}{l}\text { Inclusive economies, } \\
\text { anchor institutions. }\end{array}$ & $\begin{array}{l}\text { Agglomeration model and } \\
\text { inclusive growth. }\end{array}$ \\
\hline $\begin{array}{l}\text { Official } \\
\text { position }\end{array}$ & $\begin{array}{l}\text { Growth and public } \\
\text { sector reform. }\end{array}$ & Cooperative borough. & $\begin{array}{l}\text { No one held back, no one left } \\
\text { behind ('Vision 2031'). }\end{array}$ \\
\hline $\begin{array}{l}\text { Public } \\
\text { sector } \\
\text { reform } \\
\text { agenda }\end{array}$ & $\begin{array}{l}\text { Place-based reform. } \\
\text { Community } \\
\text { leadership } \\
\text { programme. }\end{array}$ & $\begin{array}{l}\text { Social value. } \\
\text { Asset based approach to } \\
\text { communities. } \\
\text { In-sourcing - bringing } \\
\text { services back in house. }\end{array}$ & $\begin{array}{l}\text { Contracting out. } \\
\text { Commercialised services. } \\
\text { Shared services. } \\
\text { Physical asset maximisation. } \\
\text { Prudential investment. }\end{array}$ \\
\hline $\begin{array}{l}\text { Represents } \\
\text { critique of: }\end{array}$ & Centralisation. & $\begin{array}{l}\text { Privatisation and New } \\
\text { Public Management. }\end{array}$ & High tax local government. \\
\hline
\end{tabular}

